South African Journal of Animal Science 2021, 51 (No. 2)

\title{
Inclusion of rapeseed and pumpkin seed cakes in diets for Murciano-Granadina goats alters the fatty acid profile of milk
}

\author{
I.M. Boldea, C. Dragomir", M.A. Gras \& M. Ropotă \\ National Research and Development Institution for Biology and Animal Nutrition, IBNA, Balotești, Calea \\ București, nr. 1, Romania
}

(Received 18 March 2020; Accepted 26 February 2021; Published 16 April 2021)

\begin{abstract}
Copyright resides with the authors in terms of the Creative Commons Attribution 4.0 South African Licence.
See: http://creativecommons.org/licenses/by/4.0/za

Condition of use: The user may copy, distribute, transmit and adapt the work, but must recognise the authors and the South African Journal of Animal Science.
\end{abstract}

\begin{abstract}
The objective of this research was to assess the effects of including oil-rich feedstuffs in diets for lactating goats on the fatty acid (FA) profile of their milk. Thirty-six Murciano-Granadina goats were randomly assigned to three treatment groups, namely a control diet (CTRL), a diet based on whole rapeseed (RS), and a diet based on pumpkin seed cake (PSC). The diets were composed of $1 \mathrm{~kg}$ hay (70\% Italian ryegrass, $30 \%$ alfalfa) and $1.24 \mathrm{~kg}$ concentrate, and were formulated to be isoenergetic and isonitrogenous. Milk yield and its contents of protein, fat and lactose did not differ significantly among the groups. However, including oil-rich feeds in the diet altered the fatty acid profile of the milk significantly, decreasing its saturated fatty acid (SFA) content and increasing its content of unsaturated fatty acids (UFAs). Effects on polyunsaturated fatty acids (PUFAs), conjugated linoleic acid (CLA), and the n-6 to n-3 ratio depended on the source of dietary lipids. The PSC augmented diet increased the relative amount of PUFAs and fatty acid methyl esters (FAME) in milk (+25\%) significantly In comparison with CTRL, whereas the RS diet produced a limited and statistically insignificant increase $(+7.5 \%)$. The concentration of CLA was higher in milk from does fed the PSC diet, whereas the n-6 to n-3 ratio was lower in milk from does fed RS. These preliminary results form the basis for developing premium dairy products that are enriched in fatty acids that are more favourable for human health.
\end{abstract}

Keywords: oilseeds, premium dairy products, unprotected dietary lipids

"Corresponding author: catalin.dragomir@ibna.ro

\section{Introduction}

Although milk represents a major source of nutrients for human nutrition (Pereira 2014), there is concern that high consumption of milk fat (Ventto et al., 2017) is a source of health problems for the consumers. The fat is one of the most important components of goat milk, because of its nutritional value, physical and sensory characteristics (Amigo \& Fontecha, 2011). The main component of milk fat is represented by the triglycerides, made up of almost $60 \%$ SFA, about $30 \%$ monounsaturated fatty acids (MUFAs) and a lower content of PUFA, as a result of ruminal biohydrogenation (Valdez-Arjona \& RamírezMella, 2019). Indeed, the FA composition of the milk fat produced by ruminant animals was influenced significantly by ingestion of dietary lipids (Toral et al., 2018).

Some SFAs that are common in milk, such as lauric acid (C12:0), myristic acid (C14:0), and palmitic acid (C16:0), are highlighted by nutritionists for their negative effects on consumer health, especially the risk of cardiovascular diseases. But milk and dairy products are a major source of SFAs for human nutrition (Gebreyowhans et al., 2019). Consequently, researchers and practitioners try to find practical methods to improve the milk FA profile to lower the incidence of associated chronic diseases (Shingfield et al., 2013) and even to enhance consumer health by providing them with functional foods. A more beneficial profile of FAs refers to increased amounts of unsaturated FAs (UFAs), with the emphasis on PUFAs (Morsy et al., 2015) and a lower n-6 to n-3 PUFA ratio (Husted \& Bouzinova, 2016).

Milk FA composition can change significantly in response to the feeding regimen (Ollier et al., 2009) and the improvement of the quality of dairy products through tailored feeding strategies is a feasible and often successful approach. However, because of the high diversity of feed particularities and the complexity 
of the ruminal environment (for example on animal species and category), there are many gaps in knowledge of the effects of these strategies and on the mechanisms involved.

The most common feeding strategy to improve the milk FA profile is supplementation with dietary fat sources (Cappucci et al., 2018; Kliem et al., 2019; Gebreyowhans et al., 2019), such as oilseeds. Oilseeds are rich sources of UFAs, predominantly oleic, linoleic and linolenic acid, and their inclusion in ruminant diets can lead to changes in the lipid metabolism and mammary secretion of FA. Oilseed cakes, which are byproducts of the cold-press oil extraction process, are an underutilized protein source (Popović et al., 2017) but have a fairly high content of residual fat.

The classical approach, with acknowledged positive effects on the ruminant milk FA profile, is the inclusion of linseed in the diet (Tudisco et al., 2014; Martínez Marín et al., 2015, Castro et al., 2019). Also, the use of rapeseed (Brassica napus) in ruminant diets in the form of pure oil (Inglingstad et al., 2017), rapeseed meal, rapeseed cakes and partially processed seeds (Schmidely, 2011; Lerch et al., 2012; Brask et al., 2013) was frequently reported, but results on the effects of whole seeds are scarce.

The lipids contained in rapeseed ('canola' in Canada and United States) are characterized by low quantities of SFAs (less than 7\%) (Ghazani \& Marangoni, 2016) compared with other common vegetable oils, which makes it an excellent choice as low SFAs are the target of diet formulation (Aukema \& Campbell, 2011). When the whole seed is used, the strong pericarp could prevent rumen degradation (Huard et al., 1998), thus the lipid fraction may have reduced vulnerability to ruminal biohydrogenation, leading to greater amounts of UFAs being available for further digestion and absorption processes (Hoffmann et al., 2016). However, research results are incomplete and inconsistent.

Although sunflower, soybean, and rapeseed are processed mainly in factories that are able to extract most of the oil, the other oilseeds are processed in small factories, using cold-press extraction, which leads to by-products (cakes) that have a high content of residual oil, which is a valuable source of energy and of particular FAs for animal diets.

Pumpkin seed (Cucurbita sp.) cake is a good example. Pumpkin seeds are a valuable nutritional source, with positive effects in human diets (Patel, 2013) and are a high natural source of magnesium, vitamins and MUFAs, which are favourable for the heart function (Senyilmaz-Tiebe et al., 2018). Pumpkin seed oil, which is still found in fairly high quantities in the cold-pressed cakes, is known for its strong antioxidant activity, being a highly unsaturated oil (Stevenson et al., 2007). Various studies have confirmed the properties of Cucurbita maxima and Cucurbita pepo L. seeds, and their chemical composition, but, except for Klir et al. (2017), there are apparently no data on the inclusion of pumpkin seeds, oil and pumpkin seed cake in dairy goat diets.

The objective of the experiment was to assess the effects of two dietary strategies on the FA profile of milk produced by dairy goats, one based on RS and the other on PSC.

\section{Material and methods}

The experiment complies with Directive 2010/63/EU on the protection of animals used for scientific purposes. All the procedures involving animals were approved by the Ethical Commission of National Research and Development Institute for Biology and Animal Nutrition, Balotesti, Romania.

The experiment and was conducted at Agrivalahia dairy goat commercial farm, in south-east Romania beginning in mid August. It lasted for 28 days (seven days for adaptation to the diets and 21 days for data collection). Thirty-six multiparous Murciano-Granadina goats were randomly assigned to three dietary treatment groups CTRL $(N=12), R S(N=12)$, and PSC $(N=12)$. This resulted in groups of does that were comparable in age, days in milk (DIM) and milk yield (Table 1).

Table 1 Description of Murciano-Granadina dairy goats that were allotted to each treatment at the beginning of the experiment

\begin{tabular}{lrrr}
\hline & \multicolumn{1}{c}{ CTRL } & \multicolumn{1}{c}{ RS } & PSC \\
\hline Age, years & $4.00 \pm 0.94$ & $4.05 \pm 1.44$ & $4.15 \pm 1.44$ \\
Days in milk & $243.33 \pm 145.23$ & $242.67 \pm 139.43$ & $243.00 \pm 139.43$ \\
Average milk yield, kg/day & $1.27 \pm 0.43$ & $1.25 \pm 0.59$ & $1.24 \pm 0.59$ \\
& & & \\
\hline
\end{tabular}

CTRL: control, RS: rapeseed, PSC: pumpkin seed cake 
The rapeseed (Brassica napus) in the experiment was produced by Agrivalahia farm and used in the goat diets as whole seeds. The pumpkin seed cakes (Cucurbita maxima) were purchased from a local oil producing company, S.C OLEOMET-S.A. S.R.L., which uses the cold-press method to extract oil, with a yield of approximately $60 \%$. Rapeseed had a lower crude fat and higher crude fibre content than the values usually reported in the literature, whereas the pumpkin seed cake had a higher crude fibre content and, consequently, a lower protein and fat content (Table 2).

Table 2 Chemical composition and profile of fatty acids methyl esters for the main dietary ingredients used this study to feed lactating Murciano-Granadina dairy goats

\begin{tabular}{|c|c|c|c|c|}
\hline \multicolumn{2}{|l|}{ Chemical composition } & Rapeseed & Pumpkin seed cake & Hay $^{1}$ \\
\hline \multicolumn{2}{|l|}{ Dry matter, $\mathrm{g} / \mathrm{kg}$} & 936.00 & 907.70 & 860.00 \\
\hline \multicolumn{2}{|l|}{ Organic matter, g/kg DM } & 958.34 & 924.86 & 932.38 \\
\hline \multicolumn{2}{|l|}{ Crude protein, g/kg DM } & 193.50 & 429.65 & 110.70 \\
\hline \multicolumn{2}{|l|}{ Crude fat, $\mathrm{g} / \mathrm{kg} \mathrm{DM}$} & 305.90 & 112.37 & 8.48 \\
\hline \multicolumn{2}{|l|}{ Crude fibre, $\mathrm{g} / \mathrm{kg} \mathrm{DM}$} & 194.60 & 230.80 & 444.88 \\
\hline \multicolumn{2}{|c|}{ Nitrogen-free extract, g/kg DM } & 264.23 & 152.03 & 368.32 \\
\hline \multicolumn{2}{|c|}{ Ash, g/kg DM } & 41.65 & 75.13 & 67.62 \\
\hline \multicolumn{5}{|c|}{ Fatty acids, g FAME $/ 100 \mathrm{~g}$ total FAME } \\
\hline Capric acid & $\mathrm{C} 10: 0$ & & 0.02 & \\
\hline Lauric acid & $\mathrm{C} 12: 0$ & & 0.01 & \\
\hline Myristic acid & $\mathrm{C} 14: 0$ & 0.14 & 0.12 & \\
\hline Pentadecanoic acid & $\mathrm{C} 15: 0$ & 0.04 & 0.08 & \\
\hline Palmitic acid & $\mathrm{C} 16: 0$ & 5.15 & 12.30 & \\
\hline Palmitoleic acid & C16:1 & 0.32 & 0.16 & \\
\hline Heptadecanoic acid & C17:0 & 0.08 & 0.07 & \\
\hline Heptadecenoic acid & $\mathrm{C} 17: 1$ & 0.17 & & \\
\hline Stearic acid & $\mathrm{C} 18: 0$ & 1.84 & 5.16 & \\
\hline Oleic cis acid & $\mathrm{C} 18: 1 \mathrm{n} 9 \mathrm{c}$ & 62.39 & 28.75 & \\
\hline Linoleic acid & C18:2n6 & 19.99 & 51.18 & \\
\hline Linolenic $\alpha$ acid & C18:3n3 & 8.26 & 0.49 & \\
\hline Linolenic $y$ acid & C18:3n3 & 0.03 & & \\
\hline Octadecatetraenoic acid & C18:4n3 & 0.38 & 0.38 & \\
\hline Arachic acid & $\mathrm{C} 20: 0$ & 0.04 & & \\
\hline Eicosadienoic acid & $\mathrm{C} 20: 2 \mathrm{n} 6$ & 0.89 & 0.07 & \\
\hline Arachidonic acid & $\mathrm{C} 20: 4 \mathrm{n} 6$ & 0.07 & & \\
\hline Behenic acid & C22:0 & & 0.13 & \\
\hline Docosadienoic acid & C22:2n6 & & 0.29 & \\
\hline Docosatrienoic acid & $\mathrm{C} 22: 3 \mathrm{n} 6$ & & 0.19 & \\
\hline Eicosapentaenoic acid & C20:5n3 & & 0.26 & \\
\hline Lignoceric acid & C24:0 & & 0.29 & \\
\hline Other fatty acids & & 0.23 & 0.05 & \\
\hline
\end{tabular}

${ }^{1}$ Italian ryegrass and alfalfa hay (70:30 mixture)

FAME: fatty acid methyl esters

All three diets were formulated to be isoenergetic and isonitrogenous (Table 3 ). Therefore, as the proportion of energy supplied by the dietary fats increased, the dietary carbohydrates decreased, with the amounts of corn and barley in the dietary treatments being adjusted accordingly. Likewise, the sunflower 
meal was retained in the RS diet to compensate the low protein content of the rapeseed. However, inclusion of sunflower meal in the PSC diet was not necessary to maintain a protein content that was similar to the CTRL diet.

Table 3 Experimental diets for feeding lactating dairy goats and their nutritive contents

\begin{tabular}{|c|c|c|c|}
\hline Ingredients & CTRL & RS & PSC \\
\hline $70 \%$ Italian ryegrass and $30 \%$ alfalfa hay, $\mathrm{kg} /$ day & 1.00 & 1.00 & 1.00 \\
\hline Concentrate mixture, $\mathrm{kg} / \mathrm{day}$ & 1.24 & 1.24 & 1.24 \\
\hline \multicolumn{4}{|l|}{ Concentrate mixture ingredients, \% } \\
\hline Corn grains & 54.90 & 46.80 & 48.40 \\
\hline Barley & 29.00 & 28.20 & 37.10 \\
\hline Sunflower meal & 13.70 & 10.50 & \\
\hline Whole rapeseed & & 12.10 & \\
\hline Pumpkin seed cake & & & 12.10 \\
\hline Monocalcium phosphate & 0.80 & 0.80 & 0.80 \\
\hline Calcium carbonate & 0.80 & 0.80 & 0.80 \\
\hline Salt & 0.80 & 0.80 & 0.80 \\
\hline \multicolumn{4}{|l|}{ Nutritional content of the diets } \\
\hline Dry matter, kg/day & 1.92 & 1.92 & 1.91 \\
\hline Net energy for lactation, UFL ${ }^{1} / \mathrm{kg} \mathrm{DM}$ day) & 1.81 & 1.83 & 1.81 \\
\hline PDIN $^{2}, g /$ day & 167.90 & 168.40 & 167.60 \\
\hline $\mathrm{PDIE}^{3}, \mathrm{~g} /$ day & 187.40 & 174.09 & 181.40 \\
\hline Ether extract, g/day & 43.49 & 100.17 & 61.30 \\
\hline Calcium, g/day & 12.40 & 12.71 & 12.59 \\
\hline Phosphorus, g/day & 8.57 & 8.59 & 8.41 \\
\hline
\end{tabular}

CTRL: control, RS: rapeseed, PSC: pumpkin seed cake

${ }_{1}^{1}$ Milk feed unit, according to INRA system, 2007; 1 UFL $=1700 \mathrm{kcal}$

2 Protein truly digested in the small intestine when the protein is the limiting factor, according to INRA system, 2007

${ }^{3}$ Protein truly digested in the small intestine when the energy is the limiting factor, according to INRA system, 2007

The goats were group-fed with restricted quantities to meet their nutritional requirements, calculated based on their weight, physiological status and targeted milk production. The animals had permanent access to fresh water. The goats were milked twice a day, at $06 \mathrm{~h} 00$ and $16 \mathrm{~h} 30$. Milk yield was recorded individually, and two sets of milk samples were collected individually, two days consecutively, at the end of the experiment: one set in $50 \mathrm{~mL}$ tubes, for proximate analyses and one set in $100 \mathrm{~mL}$ tubes, for FA determination. The proximate analyses were performed on the sampling day. To determine FAs, the samples were stored at $-20^{\circ} \mathrm{C}$ until the analyses were done.

The crude protein (CP) of the dietary ingredients was established with the Kjeldahl reference method using a semiautomatic Kjeltek auto 1030 (FOSS Tecator AB, Höganäs, Sweden) according to SR EN ISO 5983-2:2009 (International Organization for Standardization, 2009). The fat was extracted with continuous extraction in solvent, followed by fat measurement with Soxhlet after solvent removal (FOSS Tecator AB, Höganäs, Sweden) (SR ISO 6492: 2001) (International Organization for Standardization, 2001). Dry matter was measured with a gravimetric method after drying samples at $103^{\circ} \mathrm{C}$ to constant weight in an oven (BMT model ECOCELL Blueline Comfort, Nuremberg, Germany) (Regulation (CE) 152/2009) and crude ash was ascertained by heating the samples at $550{ }^{\circ} \mathrm{C}$ for 24 hours using an ashing furnace (Nabertherm Labotherm L15/11/ P320 Comfort, Bremen, Germany) (Regulation (CE) 152/2009).

Milk fat, protein and lactose were determined by FTIR rotation scanning (FTIR LactoScope) with a CombiScope FTIR 200 device (Delta Instruments, Drachten, Holland) (ISO 9622:2013).

The FA composition of the milk and dietary ingredients was determined by gas chromatography (SR EN ISO 12966-2:2017 and SR CEN ISO/TS 17764-2:2008). Perkin Elmer gas chromatograph (Clarus 500, 
USA) with capillary column injection system, flame ionization detector (FID) and column of high polarity stationary phase (SGE forte GC capillary column BPX70, $60 \mathrm{~m} ; 0.25 \mathrm{~mm}$ inner diameter) were used to verify FAME.

The effects of diets were assessed with the general linear model procedure of Minitab software (version 16, Minitab® Statistical Software), with treatment as a fixed effect, according to this model:

$$
y_{i j}=\mu+t_{i}+e_{i j}
$$

where: $Y_{i j}=$ the dependent variable,

$t_{i}=$ the treatment and

$e i_{i}=$ the error.

The analysis of variance was followed by Tukey's test to distinguish the significant differences among the diets. Statistical significance was declared at $P<0.05$. For $P$-values between 0.05 and 0.10 , the differences were regarded as indicating tendencies.

\section{Results and discussion}

The most abundant FA in rapeseed is oleic acid, followed by linoleic, linolenic and palmitic acids. In PSC, linoleic acid had the highest proportion, followed by oleic and palmitic acid (Table 3). Their concentrations were in the range reported by other authors (Mitra et al., 2009; Rezig et al., 2012). Although the level of dietary fat supply varied among the three groups, the FA profile of the feeds (RS, PSC) determined the FA supplies of the overall diets. For instance, RS group was fed a higher quantity of fat than PSC group, but the palmitic acid supplementation was still lower for animals consuming rapeseed.

Goat milk yield and proximate milk quality were not influenced significantly by the experimental diets (Table 4). Previous studies such as Chichlowski et al. (2005), Ollier et al. (2009) and Schmidely \& Andrade (2011) reported that higher yields of fat, protein and lactose were induced by the inclusion of rapeseed products such as ground canola seed, intact rapeseed and rolled canola seed in the diets for ruminants. In the present study, the RS group produced a non-significant but numerically higher milk yield and milk protein and fat content than the other two treatments. These divergent results might be partly explained by dietary energy and protein being nearly identical among the groups.

Table 4 Milk yield, milk constituents yield and milk composition for dairy goats fed a control diet, a diet supplemented with rapeseed and a diet supplemented with pumpkin seed cake

\begin{tabular}{lccccc}
\hline Specification & CTRL & RS & PSC & SE & $P$-value \\
\hline Milk yield, kg/day & $1.28 \pm 0.10$ & $1.41 \pm 0.09$ & $1.24 \pm 0.12$ & 108.2 & 0.517 \\
Milk fat, \% & $4.42 \pm 0.22$ & $4.12 \pm 0.18$ & $4.74 \pm 0.31$ & 0.248 & 0.204 \\
Milk protein, \% & $3.74 \pm 0.12$ & $3.67 \pm 0.12$ & $3.94 \pm 0.18$ & 0.145 & 0.447 \\
Lactose, \% & $4.53 \pm 0.05$ & $4.61 \pm 0.06$ & $4.46 \pm 0.04$ & 0.053 & 0.149 \\
Fat yield, g/day & $53.31 \pm 3.36$ & $55.12 \pm 2.81$ & $52.02 \pm 4.24$ & 3.572 & 0.826 \\
Protein yield, g/day & $46.08 \pm 3.12$ & $49.93 \pm 2.44$ & $45.08 \pm 4.14$ & 3.381 & 0.567 \\
Lactose yield, g/day & $58.53 \pm 4.80$ & $65.18 \pm 4.34$ & $55.12 \pm 5.43$ & 4.978 & 0.353
\end{tabular}

CTRL: control, RS: rapeseed, PSC: pumpkin seed cake

Members of bacterial and protozoal communities hydrolyse the complex dietary lipids (e.g. triacylglycerols, phospholipids, and glycolipids) into long-chain fatty acids (LCFA), glycerol, and other organic compounds in the rumen (Buccioni et al., 2012). Rumen microorganisms responsible for hydrolysis of esterified lipids exist in small numbers, but their activity is highly specific and efficient, leading to a large proportion of dietary lipids (85-95\%) reaching the duodenum in form of free FA (Loften et al., 2014a). The FAs in goat milk come from FA de novo synthesized in the mammary gland (mainly short- and medium-chain SFA) or from plasma fatty acids absorbed through the ruminal wall, that is, LCFA and MUFAs (Kompan \& Komprej, 2012). Medium-chain SFA decreased, whereas LCFA increased (Table 5), suggesting that the increase of the lipid supply in the diets was associated with a decrease of de novo synthesis of FA. 
Caproic acid in the milk increased for both the RS and PSC groups $(P=0.025)$, whereas the proportions of caprylic and capric acids were not influenced by the diet. Caprylic, capric and caproic acids are responsible for the characteristic odour and flavour of goat milk (Amigo \& Fontecha, 2011) and represent approximately $15-18 \%$ of the total FAs compared with only $5-9 \%$ in cow's milk. These FAs have higher digestibility than LCFA and their being saturated is not viewed as problematic owing to their direct availability as an energy source and because they are not stored in body tissues (Verruck et al., 2019).

The lauric acid content of the milk in the present study was reduced significantly in both RS and PSC groups in contrast to CTRL. Also, myristic and palmitic acids decreased significantly in both groups compared with CTRL, the decrease being more striking for the RS group. The cholesterol-raising potency of the SFAs was lower in the stearic acid (C18:0) but higher in the palmitic (C16:0), myristic (C14:0) and lauric $(C 12: 0)$ acids, the latter two being highly and positively correlated with higher cholesterol levels (German \& Dillard, 2010). Myristoleic (n-5) and palmitoleic acids (n-7), which are constituents of the glycerides of human adipose tissue, are biosynthesized from myristic and palmitic acid respectively. In the present study, they decreased with that their precursors.

Table 5 Fatty acid methyl ester profile of goat milk, expressed as $\mathrm{g} / 100 \mathrm{~g}$ total FAME

\begin{tabular}{|c|c|c|c|c|c|c|}
\hline Fatty acid & & CTRL & RS & PSC & SE & $P$-value \\
\hline Caproic acid & C6:0 & $1.27^{\mathrm{b}}$ & $1.46^{\mathrm{a}}$ & $1.44^{\mathrm{ab}}$ & 0.054 & 0.025 \\
\hline Caprylic acid & C8:0 & 3.12 & 3.26 & 3.32 & 0.133 & $\mathrm{~ns}$ \\
\hline Capric acid & C10:0 & 12.52 & 11.86 & 12.11 & 0.304 & ns \\
\hline Undecanoic acid & C11:0 & 0.49 & 0.45 & 0.51 & 0.169 & 0.076 \\
\hline Lauric acid & C12:0 & $7.24^{\mathrm{a}}$ & $5.82^{b}$ & $6.03^{b}$ & 0.201 & $<0.001$ \\
\hline Myristic acid & C14:0 & $12.67^{\mathrm{a}}$ & $10.79^{b}$ & $11.75^{\mathrm{a}}$ & 0.277 & $<0.001$ \\
\hline Myristoleic acid & C14:1 & $0.82^{\mathrm{a}}$ & $0.63^{b}$ & $0.71^{\mathrm{ab}}$ & 0.034 & 0.001 \\
\hline Pentadecanoic acid & C15:0 & 0.28 & 0.27 & 0.28 & 0.010 & ns \\
\hline Pentadecenoic acid & C15:1 & 1.14 & 1.06 & 1.00 & 0.058 & ns \\
\hline Palmitic acid & C16:0 & $28.28^{\mathrm{a}}$ & $22.50^{\mathrm{C}}$ & $25.59^{b}$ & 0.585 & $<0.001$ \\
\hline Palmitoleic acid & C16:1 & $2.22^{\mathrm{a}}$ & $1.68^{\mathrm{b}}$ & $1.88^{\mathrm{b}}$ & 0.073 & $<0.001$ \\
\hline Heptadecanoic acid & C17:0 & $0.36^{\mathrm{a}}$ & $0.32^{b}$ & $0.36^{\mathrm{a}}$ & 0.010 & 0.005 \\
\hline Stearic acid & C18:0 & $5.84^{\mathrm{C}}$ & $9.72^{\mathrm{a}}$ & $7.13^{\mathrm{b}}$ & 0.360 & $<0.001$ \\
\hline Oleic acid & C18:1n9-cis & $18.33^{\mathrm{C}}$ & $24.53^{\mathrm{a}}$ & $21.70^{b}$ & 0.579 & $<0.001$ \\
\hline Linoleic acid & C18:2n6-trans & $0.33^{\mathrm{c}}$ & $0.50^{\mathrm{a}}$ & $0.41^{\mathrm{b}}$ & 0.023 & $<0.001$ \\
\hline Linoleic acid & C18:2n6-cis & $1.93^{\mathrm{b}}$ & $1.92^{\mathrm{b}}$ & $2.59^{\mathrm{a}}$ & 0.073 & $<0.001$ \\
\hline Linolenic $\alpha$ acid & C18:3n3 & $0.29^{b}$ & $0.36^{\mathrm{a}}$ & $0.27^{b}$ & 0.016 & $<0.001$ \\
\hline Conjugated linoleic acid & $\operatorname{CLA}(\mathrm{c} 9, \mathrm{t} 11)$ & $0.38^{\mathrm{ab}}$ & $0.30^{\mathrm{b}}$ & $0.42^{\mathrm{a}}$ & 0.027 & 0.008 \\
\hline Eicosadienoic acid & C20:2n6 & $0.10^{\mathrm{C}}$ & $0.19^{\mathrm{a}}$ & $0.13^{b}$ & 0.008 & $<0.001$ \\
\hline Other fatty acids & & $1.25^{\mathrm{a}}$ & $1.13^{b}$ & $1.24^{\mathrm{a}}$ & 0.025 & 0.001 \\
\hline SFA, \% & & $72.48^{\mathrm{a}}$ & $66.79^{b}$ & $68.82^{b}$ & 0.613 & $<0.001$ \\
\hline MUFA, \% & & $22.95^{\mathrm{c}}$ & $28.32^{\mathrm{a}}$ & $25.73^{b}$ & 0.578 & $<0.001$ \\
\hline PUFA, \% & & $3.32^{b}$ & $3.57^{\mathrm{b}}$ & $4.13^{\mathrm{a}}$ & 0.101 & $<0.001$ \\
\hline UFA, \% & & $26.27^{b}$ & $31.89^{\mathrm{a}}$ & $29.86^{\mathrm{a}}$ & 0.604 & $<0.001$ \\
\hline$n-3$ fatty acids & & $0.33^{b}$ & $0.42^{\mathrm{a}}$ & $0.34^{\mathrm{b}}$ & 0.018 & 0.001 \\
\hline$n-6$ fatty acids & & $2.60^{\mathrm{b}}$ & $2.85^{\mathrm{b}}$ & $3.38^{\mathrm{a}}$ & 0.087 & $<0.001$ \\
\hline ratio of $n-6$ to $n-3$ fatty acids & & $8.14^{\mathrm{b}}$ & $7.09^{b}$ & $10.42^{\mathrm{a}}$ & 0.405 & $<0.001$ \\
\hline
\end{tabular}

FAME: fatty acid methyl ester: CTRL: control, RS: rapeseed, PSC: pumpkin seed cake, SFA: saturated fatty acids, MUFA: monounsaturated fatty acids, PUFA: polyunsaturated fatty acids

a,b,c Within a row, means with a common superscript were not significantly different 
Although the proportion of heptadecanoic acid (C:17) in the total SFAs of ruminant milk is small, it is considered a biomarker of fat intake by consumers (Pfeuffer \& Jaudszus, 2016). It decreased in RS group ( $P$ $=0.005$ ), but was not influenced by the inclusion of PSC in the diet.

Stearic acid, a product of PUFA biohydrogenation, increased in the milk from both experimental groups. This was associated with higher supplies of dietary unsaturated fat (compared with CTRL), which led to extensive biohydrogenation processes and finally to higher amounts of stearic acid leaving the rumen, as explained by Lock (2006) and reviewed by Loften et al. (2014), who concluded that the flow of C18:0 from the rumen may be several times greater (six times according to Wu et al. (1991)) than the amount consumed by the animal. Dietary C18:0 appears to have some beneficial effects on human health (Senyilmaz-Tiebe et al., 2018). Unlike other SFAs, C18:0 does not increase the risk of atherosclerosis and reduces LDL cholesterol (Senyilmaz-Tiebe et al., 2018). However, the most significant MUFA in nature, namely oleic acid, which is synthesized during the desaturation of C18:0 fatty acids inside the mammary epithelial cells (Shi, 2019), showed a significant positive response to lipid supplementation, which was more visible in the RS diet.

Despite the low transfer efficiency from dietary to milk PUFA, caused by the ruminal biohydrogenation process (Lopez et al., 2019), PUFA quantities in ruminant milk are related strongly to the ingested amounts of these FAs (Khiaosa-Ard, 2010). The content in goat milk of linoleic acid (LA) was enhanced through administration of PSC (a rich source of LA) (Table 2) and the a-linolenic acid (ALA) content increased in the milk from the RS group $(P<0.001)$.

Linoleic acid is the main precursor of CLA. Supplementation with dietary LA is often used as a strategy for enriching the ruminant milk CLA. The CLA content in the milk from the PSC group was significantly higher than in RS group, results that were in line with the previous findings.

Even if the n-3 FA content was increased significantly in the milk from RS group, the n-6 to n-3 ratio was not statistically decreased compared with CTRL. However, it was lower than PC group, where a negative effect was noticed on the n-6 to $n-3$ ratio, presumably because of the high amount of linoleic acid, which contributed to a significant increase in total n-6 FAs.

Both RS and PSC diets had positive effects on the total SFA content of the milk, which decreased $(P$ $<0.001)$, and on the total UFA content, which increased $(P<0.001)$. Also, milk MUFA content increased in both groups $(P<0.001)$ compared with CTRL, but to a higher extent in RS than PC. On the other hand, the PSC diet led to greater quantity of total PUFAs $(+25 \%)(P<0.001)$ and higher $n-6$ to $n-3$ ratio, compared with the RS diet.

\section{Conclusions}

Alteration of dietary lipids by feeding RS and PSC in diets that were isocaloric and isonitrogenous did not have a detectable effect on milk yield or its proximate composition. However, the RS and PSC augmented diets both led to more beneficial FA profiles of the milk. Thus, including these ingredients in diets for lactating dairy goats could provide a means of producing premium milk products locally. These strategies rely on local and affordable feedstuffs, which meet the needs of farmers and consumers.

\section{Acknowledgements}

The experiment was conducted within 26PTE/2017 National Research Project, financed by UEFISCDI, Romania. The biochemical analyses and publication were supported by a grant from the Romanian Ministry of Research and Innovation, CCCDI-UEFISCDI, PN-III-1-1.2-PCCDI-2017-0473 (8PCCDI), within PNCDI III.

\section{Authors' Contributions}

All authors contributed equally.

\section{Conflict of Interest Declaration}

The authors declare that there is no conflict of interest.

\section{References}

Amigo, L. \& Fontecha, J., 2011. Milk: Goat milk. Encyclopaedia of dairy sciences. 2nd edition. Pp. $484-493$. https://www.researchgate.net/publication/288173882_Milk_Goat_Milk

Aukema, H. \& Campbell, L., 2011. Oil nutrition and utilization. Canola: $\bar{C}$ hemistry, production, processing, and utilization. 245-280. https://www.researchgate.net/publication/289975582_Oil_Nutrition_and_Utilization

Brask, M., Lund, P., Weisbjerg, M.R., Hellwing, A.L.F., Poulsen, M., Larsen, M.K. \& Hvelplund, T., 2013. Methane production and digestion of different physical forms of rapeseed as fat supplements in dairy cows. J. Dairy Sci. 96(4), 2356-2365. DOI: 10.3168/jds.2011-5239

Buccioni, A., Decandia, M., Minieria, S., Molle, G. \& Cabiddu, A., 2012. Lipid metabolism in the rumen: New insights on lipolysis and biohydrogenation with an emphasis on the role of endogenous plant factors. Anim. Feed Sci. Technol. 174. DOI: /j.anifeedsci.2012.02.009 
Calder, P., 2015. Functional roles of fatty acids and their effects on human health. J. Parenter. Enteral. Nutr. 39, 18S32S. DOI: $10.1177 / 0148607115595980$

Cappucci, A., Alves, S., Bessa, R., Buccioni, A., Mannelli, F., Pauselli, M., Viti, C., Pastorelli, R., Roscini, V., Serra, A., Conte, G. \& Mele, M., 2018. Effect of increasing amounts of olive crude phenolic concentrate in the diet of dairy ewes on rumen liquor and milk fatty acid composition. J. Dairy Sci. 101(6), 4992-5005. DOI: 10.3168/jds.201713757

Castro, T., Martinez, D., Isabel, B., Cabezas, A. \& Jimeno, V., 2019. Vegetable oils rich in polyunsaturated fatty acids supplementation of dairy cows' diets: Effects on productive and reproductive performance. Animals 9, 205. DOI: 10.3390/ani9050205

Chichlowski, M., Schroeder, J.W., Park, C., Keller, W. \& Schimek, D., 2005. Altering the fatty acids in milk fat by including canola seed in dairy cattle diets. J. Dairy Sci. 88, 3084-94. DOI: 10.3168/jds.S0022-0302(05)72990-8

Gebreyowhans, S., Zhang, S., Pang, X., Lu, J. \& Lv, J., 2019. Dietary enrichment of milk and dairy products with n-3 fatty acids: A review. Int. Dairy J. 97, 158-166. DOI: 10.1016/j.idairyj.2019.05.011

German, J. B. \& Dillard, C.J., 2010. Saturated fats: A perspective from lactation and milk composition. Lipids 45(10), 915923. DOI: $10.1007 / \mathrm{s} 11745-010-3445-9$

Ghazani, M.S. \& Marangoni, A., 2016. Healthy fats and oils. Encyclopaedia of food grains. 2nd edition. Pp. 2-4. http://digitallibrarynepal.com/hotel-management/encyclopedia-food-grains-2nd-edition-4-volume-set-2016-3005/

Hoffmann, A., Görlich, S., Steingass, H., Terry, H., Schollenberger, M., Hartung, K. \& Mosenthin, R., 2016. Milk production and milk fatty acids in dairy cows fed crushed rapeseed or rapeseed oil. Livest. Sci. 190, 31-34. DOI: 10.1016/j.livsci.2016.05.016

Huard, S., Petit, H.V., Seoane, J.R. \& Rioux, R., 1998. Effects of mechanical treatment of whole canola seeds on performance, diet digestibility and rumen parameters of lambs fed grass silage. Can. J. Anim. Sci. 78(4), 657-664. DOI: $10.4141 /$ A97-118

Husted, K.S. \& Bouzinova, E.V., 2016. The importance of $n-6 / n-3$ fatty acids ratio in the major depressive disorder. Medicina (Lithuania) 52(3), 139-47. DOI: 10.1016/j.medici.2016.05.003

Inglingstad, R.A., Skeie, S., Vegarud, G., Devold, T., Chilliard, Y. \& Eknæs, M., 2017. Feeding a concentrate rich in rapeseed oil improves fatty acid composition and flavor in Norwegian goat milk. J. Dairy Sci. 100 (9), 7088-7105. DOI: 10.3168/jds.2016-12383

Khiaosa-ard, R., Klevenhusen, F., Soliva, C., Kreuzer, M. \& Leiber, F., 2010. Transfer of linoleic and linolenic acid from feed to milk in cows fed isoenergetic diets differing in proportion and origin of concentrates and roughages. J. Dairy Res. 77(3), 331-36. DOI: 10.1017/S0022029910000257

Kliem, K.E., Humphries, D., Kirton, P., Givens, I. \& Reynolds, C., 2019. Differential effects of oilseed supplements on methane production and milk fatty acid concentrations in dairy cows. Animal 13(2), 309-317. DOI: $10.1017 /$ S1751731118001398

Klir, Z., Castro-Montoya, J., Novoselec, J., Molkentin, J., Domacinovic, M., Mioč, B., Dickhoefer, U. \& Zvonko, A., 2017. Influence of pumpkin seed cake and extruded linseed on milk production and milk fatty acid profile in Alpine goats. Animal 11(10), 1772-78. DOI: 10.1017/S175173111700060X

Kompan, D. \& Komprej, A., 2012. The effect of fatty acids in goat milk on health. Milk production - An up-to-date overview of animal nutrition, management and health. Pp. 3-28. DOI: 10.5772/50769

Lerch, S., Ferlay, A., Pomiès, D., Martin, B., Pires, J. \& Chilliard, Y., 2012. Rapeseed or linseed supplements in grassbased diets: Effects on dairy performance of Holstein cows over two consecutive lactations. J. Dairy Sci. 95(4), 1956-70. DOI: 10.3168/jds.2011-4575

Lock, A.L., Harvatine, K., Drackley, J. \& Bauman, D., 2006. Concepts of fat and fatty acid digestion in ruminants. Proc. Cornell Nutr. Conf. (January). Pp. 85-100. https://www.canr.msu.edu/dairynutrition/animal_nutrition/publications

Loften, J.R., Linn, J., Drackley, J., Jenkins, T., Soderholm, C. \& Kertz, A., 2014. Invited review: Palmitic and stearic acid metabolism in lactating dairy cows. J. Dairy Sci. 97(8), 4661-74. DOI: 10.3168/jds.2014-7919

Lopez, A., Vasconi, M., Moretti, V. \& Bellagamba, Fe., 2019. Fatty acid profile in goat milk from high- and low-input conventional and organic systems. Animals 9, 1-14. DOI: 10.3390/ani9070452

Martínez Marín, A.L., Gómez-Cortés, P., Núñez Sánchez, N., Juárez, M., Garzón Sigler, A., Blanco, F. \& De la Fuente, M., 2015. Associations between major fatty acids in plant oils fed to dairy goats and C18 isomers in milk fat. J. Dairy Res. 82(2), 152-160. DOI: 10.1017/S002202991500014X

Mitra, P., Ramaswamy, H.S. \& Chang, K.S., 2009. Pumpkin (Cucurbita maxima) seed oil extraction using supercritical carbon dioxide and physicochemical properties of the oil. J. Food Eng. 95(1), 208-213. DOI: 10.1016/j.jfoodeng.2009.04.033

Morsy, T., Kholif, S.M., Matloup, O. \& Kholif, A., 2015. Influence of sunflower whole seeds or oil on ruminal fermentation, milk production, composition, and fatty acid profile in lactating goats. Asian-Australas. J. Anim. Sci. 28(8), 11161122. DOI: $10.5713 /$ ajas. 14.0850

Ollier, S., Leroux, C., De la foye, A., Bernard, L., Rouel, J. \& Chilliard, Y., 2009. Whole intact rapeseeds or sunflower oil in high-forage or high-concentrate diets affects milk yield, milk composition, and mammary gene expression profile in goats. J. Dairy Sci. 92(11), 5544-60. DOI: 10.3168/jds.2009-2022

Patel, S., 2013. Pumpkin (Cucurbita sp.) seeds as nutraceutic: A review on status quo and scopes. Med. J. Nutrition Metab. 6(3), 183-89. DOI: 10.1007/s12349-013-0131-5

Pereira, P.C., 2014. Milk nutritional composition and its role in human health. Nutrition 30(6), 619-27. DOI: 10.1016/j.nut.2013.10.011

Pfeuffer, M. \& Jaudszus, A., 2016. Pentadecanoic and heptadecanoic acids: Multifaceted odd-chain fatty acids. Advances in Nutrition 7, 730-734. DOI: 10.3945/an.115.011387 
Popović, L., Stolić, Ž., Cakarevic, J., Torbica, A., Tomić, J. \& Šijački, M., 2017. Biologically active digests from pumpkin oil cake protein: Effect of cross-linking by transglutaminase. J. Am. Oil Chem. Soc. 94(10), 1245-51. DOI: 10.1007/s11746-017-3041-8

Rezig, L., Chouaibi, M., Msaada, K. \& Hamdi, S., 2012. Chemical composition and profile characterisation of pumpkin (Cucurbita maxima) seed oil. Ind. Crops Prod. 37(1), 82-87. DOI: 10.1016/j.indcrop.2011.12.004

Schmidely, Ph. \& Andrade, P.V.D., 2011. Dairy performance and milk fatty acid composition of dairy goats fed high or low concentrate diet in combination with soybeans or canola seed supplementation. Small Rumin. Res. 99(2-3), 135-142. DOI: 10.1016/j.smallrumres.2011.04.010

Senyilmaz-Tiebe, D., Pfaff, D.H. \& Virtue, S., 2018. Dietary stearic acid regulates mitochondria in vivo in humans. Nat. Commun. 9(1), 1-10. DOI: 10.1038/s41467-018-05614-6

Shi, H., Wang, L., Luo, J., Liu, J., Loor, J. \& Liu, H., 2019. Fatty acid elongase 7 (ELOVL7) plays a role in the synthesis of long-chain unsaturated fatty acids in goat mammary epithelial cells. Animals 9(6), 389. DOI: 10.3390/ani9060389

Shingfield, K.J., Bonnet, M. \& Scollan, N., 2013. Recent developments in altering the fatty acid composition of ruminant derived foods. Animal 7, 1-31. DOI: 10.1017/S1751731112001681

Stevenson, D.G., Eller, F.J., Wang, L., Jane, J.L., Wang, T. \& Inglett, G.E., 2017. Oil and tocopherol content and composition of pumpkin seed oil in 12 cultivars. J Agric. Food Chem. 55(10), 4005-13. DOI: 10.1021/jf0706979

Toral, P.G, Monahan, F., Hervás, G., Frutos, P. \& Moloney, A., 2018. Review: Modulating ruminal lipid metabolism to improve the fatty acid composition of meat and milk. Challenges and opportunities. Animal 12(S2), S272-S281. DOI: $10.1017 / \mathrm{S} 1751731118001994$

Tudisco, R., Grossi, M., Addi, L., Musco, N., Cutrignelli, M., Calabrò, S. \& Infascelli, F., 2014. Fatty acid profile and CLA content of goat milk: Influence of feeding system. J. Food Res. 3(4), 93. DOI: 10.5539/jfr.v3n4p93

Valdez-Arjona, L. \& Ramírez-Mella, M., 2019. Pumpkin waste as livestock feed: Impact on nutrition and animal health on quality of meat, milk, and egg. Animals 9(10), 769. DOI: 10.3390/ani9100769

Ventto, L., Leskinen, H., Kairenius, P., Stefański, T., Bayat, A.R., Vilkki, J. \& Shingfield, K.J., 2017. Diet-induced milk fat depression is associated with alterations in ruminal biohydrogenation pathways and formation of novel fatty acid intermediates in lactating cows. Br. J. Nutr. 117(3), 364-376. DOI: 10.1017/S0007114517000010

Verruck, S., Dantas, A. \& Prudencio, E., 2019. Functionality of the components from goat's milk, recent advances for functional dairy products development and its implications on human health. J. Funct. Foods. 52, 243-257. DOI: 10.1016/j.jff.2018.11.017

Wu, Z., Ohajuruka, O.A. \& Palmquist, D.L., 1991. Ruminal synthesis, biohydrogenation, and digestibility of fatty acids by dairy cows. J. Dairy Sci. 74(9), 3025-34. DOI: 10.3168/jds.S0022-0302(91)78488-9 